University of California, Hastings College of the Law UC Hastings Scholarship Repository

Faculty Scholarship

2014

\title{
Codes in Context How States, Markets, and Civil Society Shape Adherence to Global Labor Standards
}

Jodi L. Short

UC Hastings College of the Law, shortj@uchastings.edu

Michael W. Toffel

Melissa Oullet

Follow this and additional works at: http://repository.uchastings.edu/faculty_scholarship

\section{Recommended Citation}

Jodi L. Short, Michael W. Toffel, and Melissa Oullet, Codes in Context How States, Markets, and Civil Society Shape Adherence to Global Labor Standards, Regulation \& Governance (2014).

Available at: http://repository.uchastings.edu/faculty_scholarship/1190 
H A R VARD D B U S I N E S S S C H O O L

\section{Codes in Context: How States, Markets, and Civil Society Shape Adherence to Global Labor Standards}

Michael W. Toffel

Jodi L. Short

Melissa Ouellet

\section{Working Paper}

13-045

September 8, 2014 


\title{
Codes in Context: \\ How States, Markets, and Civil Society \\ Shape Adherence to Global Labor Standards
}

Michael W. Toffel

Harvard Business School

Boston, MA 02163

mtoffel@hbs.edu

\author{
Jodi L. Short \\ University of California \\ Hastings College of the Law \\ San Francisco, CA 94102 \\ shortj@uchastings.edu
}

\author{
Melissa Ouellet \\ Harvard Business School \\ Boston, MA 02163 \\ melissa.ouellet@gmail.com
}

September 8, 2014

\begin{abstract}
Transnational business regulation is increasingly implemented through private voluntary programs - like certification regimes and codes of conduct - that diffuse global standards. But little is known about the conditions under which companies adhere to these standards. We conduct one of the first large-scale comparative studies to determine which international, domestic, civil society, and market institutions promote supply chain factories' adherence to the global labor standards embodied in codes of conduct imposed by multinational buyers. We find that suppliers are more likely to adhere when they are embedded in states that participate actively in the ILO treaty regime and that have stringent domestic labor law and high levels of press freedom. We further demonstrate that suppliers perform better when they serve buyers located in countries where consumers are wealthy and socially conscious. Taken together, these findings suggest the importance of overlapping state, civil society, and market governance regimes to meaningful transnational regulation.
\end{abstract}

Keywords: Transnational regulation; Labor standards; Consumer politics; Codes of conduct; Compliance

\section{Introduction}

In the last several years, a series of highly publicized factory fires and building collapses that killed thousands of factory workers in Southeast Asia has focused attention on abusive labor conditions in global supply chain factories, prompting calls for more stringent regulation. Such calls are merely the latest in more than a century of efforts to raise global labor standards.

Historically, these efforts have been driven by states, through domestic labor law, participation in intergovernmental organizations (IGOs) like the International Labour Organization (ILO), and trade agreements. As economic globalization has extended supply chains around the globe, outside the reach of any one state's jurisdiction, the locus of efforts to improve global workplace 
conditions has shifted from states and IGOs to private entities like multinational corporations (MNCs), nongovernmental organizations (NGOs), and multi-stakeholder certification regimes. Even as these public and private institutions proliferate (Bartley 2011), little is known about the particular institutional conditions associated with better conditions in supply chain factories. This paper seeks to fill that gap. It provides one of the first large-scale quantitative studies of supplier-factory adherence to the global labor standards embodied in private codes of conduct. Our data include 44,838 social audits of 21,836 establishments in 12 industries and 47 countries, enabling us to conduct the first evaluation of private actors' adherence to global labor standards across a wide range of domestic contexts characterized by varying configurations of institutional pressures from international, domestic, civil society, and market actors. In addition, our study is among the first to examine whether institutional conditions in the developed markets where most MNCs are located have any relationship to labor conditions in their developingmarket supply chains.

We find greater adherence to the global labor standards embodied in codes of conduct among supplier factories that are embedded in states that actively participate in the ILO treaty regime and that have highly protective labor law and high levels of press freedom. We also find greater adherence among supplier factories that serve buyers located in countries where consumers are wealthy and socially conscious. These findings demonstrate the important roles played by state, civil society, and market institutions in transnational business regulation and substantially advance our understanding of how these regulatory institutions shape private firms' adherence to global norms. 


\section{Theoretical framework and empirical context}

Scholars have long wrestled with the question of how global norms spread and when they are followed, but the bulk of this literature focuses on norm adherence by states rather than by private actors. For instance, there is a vigorous and long-standing theoretical debate in the international-relations literature about the conditions under which states comply with the treaties they ratify (Chayes \& Chayes 1995; Goldsmith \& Posner 2005; Hathaway 2005) and a growing empirical literature identifies the factors predicting states' adherence to treaties (e.g., HafnerBurton \& Tsutsui 2005; Simmons 2009) and other transnational legal obligations (Greenhill 2010; Linos 2007). It is not clear, however, that the same factors will promote adherence by private business entities like supplier factories.

Many businesses have agreed to abide by global norms through contractual codes of conduct or participation in other voluntary programs espousing these norms. A significant body of literature explores why companies adopt these programs (e.g., Campbell 2007; Marx 2008; King \& Toffel 2009; Berliner \& Prakash 2013), but less is known about the conditions under which they actually adhere to the espoused norms.

Regulation and governance scholarship has long theorized that transnational business regulation is most effective when implemented through layered regulatory designs that weave together the competencies of multiple reinforcing regulatory institutions (Keck \& Sikkink 1998; Braithwaite \& Drahos 2000; Abbott \& Snidal 2009; Scott 2012; Eberlein et al. 2014). Several empirical studies have identified institutions that promote or hinder the effective implementation of global labor standards in supply chain factories (e.g., Rodríguez-Garavito 2005; Locke \& Romis 2007; Seidman 2007; Kocer \& Fransen 2009; Locke, Rissing, \& Pal 2013). For instance, in his study of two Central American garment factories, Rodríguez-Garavito (2005) highlights 
the key roles played by advocacy groups, branded buyers, and buyer- and supplier-country government officials in advancing workers' freedom of association rights under codes of conduct adopted by their employers. Studying two suppliers, Locke, Rissing, and Pal (2013) highlight the importance of state regulatory capacity by showing that code-of-conduct adherence was better in the country with a more active government enforcement regime. Several studies have suggested that complementary relationships between public and private labor monitoring can enhance standards adherence (Amengual 2010; Coslovsky \& Locke 2013; Locke, Rissing, \& Pal 2013). Consistent with the prevailing theoretical framework, these studies demonstrate the important role of civil society actors and reinforcing public and private regulatory institutions in promoting adherence to global labor standards. However, because this research tends to be based on intensive case studies of a small number of firms in a single industry operating in one or two countries, it tends to address a limited range of mechanisms.

Some quantitative studies have used larger samples of firms to investigate the factors that predict supplier factories' adherence to global labor standards. This research has found better adherence among factories that supply buyers that are members of multistakeholder initiatives (Oka 2010a) or that require strict internal quality controls (Ang et al. 2012) and among factories with long-standing collaborative relationships with their buyers (Locke, Qin, \& Brause 2007; Oka 2010b). Within Nike's supply chain, adherence is highest among foreign-owned factories, factories visited frequently by Nike corporate representatives, and factories in countries with strong rule-of-law norms (Locke, Qin, \& Brause 2007; Locke 2013). While this body of research has identified important mechanisms shaping the conditions under which private entities like supplier factories adhere to global labor norms, it also has limitations that risk undermining general applicability. Most of these studies were conducted using data from a single country or 
supply chain and therefore cannot speak to the relative influence of different international, domestic governmental, and civil society institutions. While the studies of Nike's supply chains across different domestic contexts do provide such variation, they focus on the influence of program design and business relationships rather than on regulatory institutions.

Our study seeks to build on this existing research and overcome some of its limitations. We analyze data from tens of thousands of audits conducted in 47 countries by one company that audits supplier factories' adherence to global labor standards embodied in the codes of conduct imposed by their MNC buyers. Our comparison across different institutional contexts answers calls for more empirical scholarship to identify precisely how different regulatory institutions influence adherence to the global norms promoted by transnational regulatory regimes (Eberlein et al. 2014).

Because we examine only firms subjected to codes and monitoring, we do not purport to contribute to the ongoing debate about whether codes and monitoring are themselves mechanisms that drive improvements in labor practices at supplier factories (e.g., RodríguezGaravito 2005; Shamir 2005; Locke \& Romis 2007; Kocer \& Fransen 2009). In our study, we consider codes of conduct to be the vehicle for communicating global labor standards to supplier factories and social monitoring to be a measure of factories' adherence to these standards. Code audits provide a novel and important window into the conditions under which private entities like supplier factories adhere to global labor standards.

\section{Institutional determinants of adherence to codes of conduct}

Private transnational regulation is characterized by cross-cutting layers of regulatory institutions and actors (Bartley 2011). Influential institutions identified in the literature include intergovernmental institutions (Börzel \& Risse 2010; Abbott \& Snidal 2012), domestic legal 
institutions (Seidman 2007; Vogel 2008; Büthe 2010; Bartley 2011; Locke 2013), civil society institutions (Marx 2008; Börzel \& Risse 2010), and market pressures (Marx 2008; Börzel \& Risse 2010). Below, we theorize and test the influence of each of these institutions on supply chain factories' adherence to the global labor standards embodied in corporate codes of conduct.

\subsection{State-based institutions}

\subsubsection{Intergovernmental institutions}

Treaties and the intergovernmental organizations implementing them are important in diffusing global norms and applying pressure to comply with international consensus standards (Lim \& Tsutsui 2012). The ILO has developed numerous standards for the protection of workers' rights embodied in conventions that state-parties to the treaty establishing the ILO may elect to ratify as legally binding obligations. The ILO monitors ratifying governments' compliance with these conventions and provides compliance assistance to national regulators, but lacks sanctioning authority to enforce convention obligations on ratifying states. Although international legal institutions like the ILO only explicitly address the conduct of states, not of companies, some observers have suggested that these institutions can play an important role in diffusing transnational norms more broadly to influence the conduct of private entities (Börzel \& Risse 2010). For instance, Abbott and Snidal (2009: 85) argue that when states reach consensus on international standards, reflected in treaty ratification and membership in intergovernmental organizations, "they signal non-state actors that expectations for business conduct have changed."

Prior empirical studies have theorized, but have not demonstrated, a relationship between treaty ratification by states and the behavior of private entities within their borders (HafnerBurton \& Tsutsui 2005; Lim \& Tsutsui 2012). Thus, it is unclear whether participation by a 
supplier factory's home country in the ILO treaty regime will predict that factory's level of adherence to global labor standards. On the one hand, the ILO has been viewed as a weak enforcer of international norms and there is little evidence that it has raised the labor standards of member states (Tsogas 2001). Moreover, it does not engage in the kind of active orchestration of private transnational actors envisioned by Abbott and Snidal (2012) in theorizing the efficacy of international institutions. And research on human rights treaty implementation has shown that states sometimes join treaties to deflect attention from bad domestic practices (Hathaway 2005).

On the other hand, a significant body of international-law literature argues that treaties can be instruments of global norm construction and diffusion (e.g., Chayes \& Chayes 1995; Keck \& Sikkink 1998). Even when treaties are not themselves the mechanism for changing state behavior, they are often reliable signals of a state's existing normative commitments (Goldsmith \& Posner 2005; Hathaway 2005). Moreover, in our empirical context, private codes of conduct implementing global labor standards serve to reinforce the norms promoted by the ILO and also provide a source of enforcement pressure that the ILO itself lacks. Because of the potential for treaties either to signal or influence domestic normative environments, the potential for international actors like the ILO to promote adherence to global labor standards through interaction with ratifying states, and the potential for MNCs to provide a mechanism for enforcing global labor standards, we hypothesize that supplier factories in countries that have ratified more ILO conventions will exhibit greater adherence to labor codes of conduct than suppliers elsewhere.

\subsubsection{Domestic legal institutions}

Studies of adherence to private voluntary regulation in domestic contexts have demonstrated that companies are more likely to adopt such regulation and implement it 
effectively when they are embedded in a robust governmental regulatory regime that holds the background threat of sanctions (Short \& Toffel 2008, 2010). Although states typically do not have the authority to sanction multinational companies operating within their borders for violations of global standards, it is often argued that transnational business regulation is more effective when it is supported by credible domestic regulation (Büthe 2010; Vogel 2008).

Empirical research suggests that domestic legal environments do indeed shape businesses' adherence to global labor standards. Locke, Qin, and Brause (2007), for instance, find better adherence to private labor codes among establishments in countries with strong ruleof-law norms. Kocer and Fransen (2009) find that the implementation of code-of-conduct standards can be impeded by conflicting domestic law. Conversely, Locke, Rissing, and Pal (2013) show how codes are more widely observed when they are supported by more stringent government regulatory regimes. We therefore hypothesize that suppliers in countries with highly stringent labor law will exhibit greater adherence to the global labor standards embodied in codes of conduct than suppliers elsewhere.

\subsection{Supplier-country civil society institutions}

The literature on transnational business regulation envisions private parties such as international nongovernmental organizations (INGOs), unions, and the press as "a counterbalance to corporate power" (Campbell 2007: 958). A substantial literature suggests that INGOs can act as diffusers, monitors, and even enforcers of global norms, with the power to impose reputational penalties on firms that violate them (Ayres \& Braithwaite 1992; Fung, O’Rourke, \& Sabel 2001). Mattli and Woods (2009: 28), for instance, argue that INGOs can play "a prominent oversight role by creating their own global monitoring schemes or feeding into or coopting existing oversight structures." 
Empirical studies have documented the important role of INGOs in promoting transnational business regulation. Lim and Tsutsui (2012) consider INGOs to be a key source of normative pressure compelling corporations to adopt the United Nations Global Compact and demonstrate that corporations are more likely to do so in countries with numerous INGOs. Many have observed the power of INGOs to "punish" companies that fail to adhere to global standards through "naming and shaming" campaigns (Seidman 2007; Soule 2009; Vogel 2008; Fransen 2012). Because INGOs can serve critical governance functions such as generating, monitoring, and enforcing norms, we hypothesize that suppliers in countries with more activist pressure from INGOs will exhibit greater adherence to labor codes of conduct than suppliers elsewhere.

A free local press can also exert regulatory pressure on supplier factories by making more credible the threat that their labor abuses will be revealed. A free press can help reveal labor abuses either through the work of local journalists or by supporting the monitoring efforts of local labor and human rights activists. An extensive body of literature suggests that companies regulate their behavior to avoid media exposure that might tarnish their image (Campbell 2007; Soule 2009; Vogel 2008). Specifically, research has demonstrated that companies implement corporate social responsibility (CSR) practices more effectively when they face the possibility of negative media coverage for poor implementation (Dyck, Volchkova, \& Zingales 2008). Although much of this research has focused on the reputational concerns of multinational brands, media exposure can be a particularly potent driver of corporate governance practices in developing markets, where firms must compete for capital from international investors (Dyck, Volchkova, \& Zingales 2008). Furthermore, local activists often work with the local media to identify and publicize abusive labor practices in supply chain factories, increasing the potential 
for government intervention, discipline from buyers, or political mobilization in local and global markets (Fransen 2012).

Because the capacity to monitor compliance and to carry out the threat of reputation damage and political mobilization is greater in countries with more press freedom, we hypothesize that suppliers in these countries will exhibit greater adherence to the global labor standards embodied in codes of conduct than suppliers elsewhere.

\subsection{Buyer-country market institutions}

There is a vigorous debate about whether demand pressure from socially conscious consumers in developed countries can motivate MNCs to improve conditions in their global supply chains. Some argue that socially conscious consumers can be the engine that drives a regulatory "race to the top" by conferring a competitive advantage on suppliers with high social standards (Fung, O’Rourke, \& Sabel 2001; Börzel \& Risse 2010). Others question whether consumers provide meaningful demand pressure for ethically produced goods, observing that "there is little evidence that consumer behavior has become more politicized: most consumers continue to make their purchasing decisions primarily, if not exclusively, on the basis of price, quality, and convenience" (Vogel 2008: 16). Although some studies have documented strong consumer demand for ethically produced goods (Hainmueller, Hiscox, \& Sequeira forthcoming), a recent comprehensive review of the literature on political consumerism concluded that the “ethical consumer" is a "myth" (Devinney, Auger, \& Eckhardt 2010).

Even so, we argue more generally that the attitudes and attributes of citizens in an MNC's home market may influence that firm's supply chain management because these attitudes reflect the potential for political mobilization. MNCs are highly sensitive to negative publicity that might damage their brand reputation with consumers, the public, and government regulators 
(Soule 2009; Vogel 2008). MNCs therefore often accede to the demands of mobilized consumers and activists to adopt CSR measures such as codes of conduct (Lenox \& Eesley 2009; Soule 2009; Fransen 2012). Sometimes the mere threat of reputational damage, even without actual political mobilization, will cause MNCs to accede to such demands (Reid \& Toffel 2009; Soule 2009). The latent threat of political mobilization may induce image-sensitive MNCs not only to adopt CSR measures, but also to implement them effectively.

The potential for political mobilization will be strongest in countries whose citizens have broadly shared frames about the value of socially conscious production (Snow et al. 1986; Zald 1996) and can afford to pay premiums for ethically produced goods (Börzel \& Risse 2010). Such environments also convey clear signals to MNCs about widely accepted norms, which MNCs risk reputational harm by violating (Vogel 2008). Thus, we argue that MNCs located "in high-end markets" where consumers "care about governance in areas of limited statehood, including human rights and environmental standards" (Börzel \& Risse 2010: 124), will be especially cautious in selecting and monitoring supplier factories. We hypothesize that these factories will, in turn, be especially likely to adhere to the global labor standards embodied in codes of conduct.

\section{Data and measures}

We obtained a proprietary dataset from a large social auditor that required anonymity as a condition of sharing its data with us. The dataset includes audit-level data for every code-ofconduct audit the firm had conducted from 2004 through 2009. Although MNCs typically draft their own codes, the substantive features of these codes are highly consistent, usually specifying international consensus standards such as the ILO core labor standards "as the appropriate benchmarks" (Abbott \& Snidal 2009: 84). They also typically call for the supplier factory to 
comply with domestic labor laws and specifically forbid practices such as child labor and prison labor, even if such practices are legal in the supplier's country or are prohibited only by unenforced laws (McBarnet \& Kurkchiyan 2007).

During our sample period, the company employed several hundred people from many countries to conduct social audits in many countries and it had already had more than a decade's experience conducting such audits. Most of the audited factories produced consumer goods, most commonly garments. To avoid the undue influence of atypical audits, we excluded audits from countries with fewer than 30 audits over the five-year sample. This resulted in a sample of 44,383 audits of 21,836 supplier establishments in 47 supplier countries on behalf of 511 buyers in 12 countries. The audits in our sample were primarily conducted in China and elsewhere in Asia, as well as in the Americas, Europe, and Africa (see Table 1). Eighty-one percent of the audits were conducted for buyers in the United States; nearly all the rest for buyers in Europe, predominantly Germany.

\subsection{Dependent variable}

We assess the extent to which supplier factories comply with private codes of conduct using the number of labor violations per audit, based on data from the social auditor database. We focused only on violations of code-of-conduct domains that apply uniformly to establishments in all industries and in all countries. According to experts familiar with these audits, these domains include child labor, forced or compulsory labor, working hours, occupational health and safety, minimum wage, disciplinary practices, treatment of foreign workers, and illegal subcontracting. ${ }^{1}$ We excluded data from code-of-conduct domains for which application of standards is known to vary across establishments, industries, and/or countries or cultural contexts; these domains include the right of association, the right to 
organize and bargain collectively, dormitory conditions, and canteen violations. ${ }^{2}$ To avoid undue influence of outliers, we winsorized (top-coded) this variable at the 99th-percentile value of 25 violations. ${ }^{3}$ The between-country variance in labor violations is 2.58 , whereas the withincountry variance is 31.60 , far greater.

We recognize that violations cited in social audits are an imperfect measure of objective labor conditions, being inevitably mediated through the perceptions and biases of the auditors. Nonetheless, we stress that our approach is consistent with the measures routinely used in the previously described literature on private auditing and in studies of compliance with domestic government regulations. For example, studies of labor standards compliance using social audit data from the Better Factories Cambodia program have characterized the results of these audits as objective measures of compliance by participating suppliers (Oka 2010a; Ang et al. 2012). Moreover, two factors attenuate concerns about measurement error in our setting. First, we rely on data from a single auditing firm, which mitigates concerns that one firm might audit more stringently than another. Second, as described below, we control for several factors commonly associated with auditor bias and competence, including which entity pays the auditor and the training and experience of audit teams.

\subsection{Independent variables}

\subsubsection{Intergovernmental institutions}

We measured the influence of intergovernmental institutions in a supplier factory's domestic environment as the number of labor treaties the host country had ratified by that year. We obtained this data from the Database of International Labour Standards maintained by the International Labour Organization (available at http://www.ilo.org). To reduce skew in our models, we used the log (after adding 1) of this count. 


\subsubsection{Domestic legal institutions}

To measure the extent to which governments provide legal protection for worker rights, we use labor laws, a composite measure developed by Greenhill, Mosley, and Prakash (2009) that indicates the extent to which domestic laws provide collective labor rights such as the rights to join unions and strike, whether government approval is required for collective bargaining, and whether laws restrict worker rights in export processing zones. ${ }^{4}$ Higher values represent greater protection of labor rights. We obtained these data from Mosley (2011b) and use the 2002 values, the most recent available. ${ }^{5}$

\subsubsection{Supplier-country civil society institutions}

We measured the extent to which audited factories risk facing activist pressures as the annual number of INGOs per million citizens (INGO density). We obtained the number of INGOs per country from the Yearbook of International Organizations (Union of International Associations, 2004-2009) and, like Lim and Tsutsui (2012), focus on federations of international organizations, universal membership organizations, intercontinental membership organizations, and regionally defined membership organizations (Categories A through D of Cluster I, using the Union of International Associations typology). We obtained annual country population data from the U.S. Census Bureau's International Data Base (http://www.census.gov/ipc/www/idb/). To reduce skew, we used the log of INGO density in our models.

We measured the extent of press freedom in the audited establishment's country via the annual Press Freedom Index produced by Reporters without Borders (available at http://en.rsf.org). This annual index incorporates direct and indirect threats to journalists; imprisonment of and physical attacks on journalists; censorship and self-censorship; legal, economic, and administrative pressure imposed on the media; and the number of journalists 
detained, murdered, and physically attacked or threatened that year. We reverse-coded this index so that higher scores represent more press freedom and rescaled press freedom to range from 0 to 1.

\subsubsection{Buyer-country market institutions}

We measured prosocial attitudes in the buyer country based on data from the World Values Survey, which polls individuals about their values and beliefs. We focused on responses to six questions that inquired about whether respondents were members of environmental organizations and consumer organizations, the extent to which they felt that "looking after the environment" was important, their willingness to give part of their income to protect the environment, their willingness to support a tax increase to prevent pollution, and whether they favored protecting the environment over economic growth and job creation. Each item was recoded, so that higher values corresponded to a more prosocial attitude, and then standardized. ${ }^{6}$ Given that the 0.78 Cronbach's alpha score indicated that the six items form an internally consistent and reliable scale, we created prosocial attitude in buyer country as the average of the standardized items. ${ }^{7}$ The vast majority of audits were conducted on behalf of buyers in Germany, (prosocial attitude of -2.1, the lowest of all countries in our sample), the United States (0.45), and Canada (2.9).

We measured the level of economic development in each buyer country based on annual data on gross domestic product (GDP) per capita in 2005 dollars obtained from the U.S. Department of Agriculture's Economic Research Service (USDA ERS, available at http://www.ers.usda.gov) and, to reduce skew, we used log GDP per capita of buyer country in our models. Buyer-country averages annual log GDP per capita during our sample period ranged from a low of $6.63(\$ 757)$ for Vietnam and to a high of $10.65(\$ 42,468)$ for the United States. 
The vast majority of audits were conducted on behalf of buyers in Germany (averaging 10.46, or $\$ 34,951$ ), Canada (averaging 10.52 , or $\$ 37,075$ ) and the United States.

\subsection{Control variables}

We controlled for the level of economic development in each audited factory's country using the log of GDP per capita, obtained from USDA ERS. We created OECD member as a dummy variable to distinguish countries in the Organisation for Economic Co-operation and Development (OECD) from developing countries because institutions might influence the private sector differently in developed versus developing countries (Greenhill, Mosley, \& Prakash 2009).

To control for economic incentives that might affect the intensity of the audit, we created three dummy variables to denote which entity paid for each audit (audit paid by buyer; audit paid by vendor, agent, or licensee; and audit paid by factory), based on the social auditor's database. We also created a dummy variable to denote the 4,001 audits ( $9 \%$ of the sample) for which the payer was not identified in the database; estimating our model excluding these audits yielded nearly identical results and did not affect our inferences.

Because government inspectors' experience affects their ability to identify violations (Bardach \& Kagan, 1982/2002), we created audit team tenure as the average number of years the members of each audit team had worked at the auditing company. To further account for auditor competence, we also control for audit skills training by calculating the average number of the auditing firm's training courses that all audit team members had completed by the date the audit occurred. Data for both of these variables came from the social auditor's anonymized personnel records. 
We created re-audit as a dummy variable to distinguish routine audits from re-audits, which tend to focus more narrowly on domains with prior violations and thus are likely to lead to fewer violations being recorded. We created the dichotomous variable third-party audit protocol to control for the possibility that audit results might be affected by the use of a third-party audit protocol such as those of the International Council of Toy Industries (ICTI) and the Sedex Members Ethical Trade Audit (SMETA). We controlled for the number of auditors assigned to each audit because our interviews with experienced social auditors indicated this is a reasonable proxy for factory size and complexity. We obtained all three of these audit-related variables from the auditor's database. ${ }^{8}$ We created a dummy variable coded 1 for the 156 audits $(0.3 \%$ of the sample) for which the number of auditors was missing in the auditor database and was therefore recoded from "missing" to 0 ; the dummy was coded 0 otherwise.

To control for differences in the risk of violations at audited factories across different industries, we derived information from the social auditor's database about each factory's industry and coded dummy variables for the following industries: accessories; building materials; chemicals and plastics; electronics; food, agriculture, and beverage; footwear; furniture; garments; metal products; paper, printing, and publishing; services; and toys. We also created an industry undetermined dummy to denote the 18,681 audits ( $42 \%$ of the sample) for which we could not identify the audited factory's industry; results were nearly identical and our inferences were unchanged when we estimated the model excluding these audits from the sample. A robustness test that relied on multiple imputation to estimate missing industry values yielded results nearly identical to those of our primary approach. ${ }^{9}$

Because successive audits might yield fewer violations as factories addressed the violations cited in prior audits, we created a series of dummies to indicate a factory's audit 
sequence; that is, to indicate whether an audit was a factory's first, second, third, fourth, fifth, or sixth-or-more in the sample (only three percent of the audits in our sample were a factory's seventh or higher audit). We include a full set of year dummies to account for annual differences in the attention to supply chain labor issues and for global economic cycles driving demand for labor and for the goods produced by the audited factories.

Table 2 reports the industry composition of our sample and Table 3 reports summary statistics and correlations. ${ }^{10}$

\section{Empirical model and results}

To facilitate interpretation, our models use standardized versions of labor treaties, labor laws, INGO density, press freedom, and prosocial attitude in buyer country. Because the dependent variable is a count variable that exhibits overdispersion, with a 5.4 ratio of the variance (34.69) to the mean (6.38), we estimate the model using negative binomial regression. Because many of our annual variables are measured at the audited-establishment's-country level, we cluster standard errors by the establishment's country. A robustness test that clustered standard errors two ways — by the audited establishment's country and by the buyer's countryyielded results nearly identical to those of our primary approach. ${ }^{11}$

Regression results of our primary model are reported in Column 1 of Table 4 as coefficients and average marginal effects (AME). The model fit statistics of our primary model—McFadden's Adjusted R-squared of 0.048, a Likelihood Ratio of 12603.8, and a Bayesian Information Criterion (BIC') of -12165.0 -indicate significant improvement over alternative parsimonious models that (a) omit all variables except industry dummies; (b) omit all supplier-country variables; and (c) omit all buyer-country variables. ${ }^{12}$ 
We begin by presenting the results related to intergovernmental and domestic governmental activities. Establishments in countries that have ratified more ILO conventions exhibit greater adherence to labor codes of conduct at marginal levels of statistical significance $(\beta=-0.04, p=0.07)$. The AME indicates that a one-standard-deviation increase in standardized labor treaties is associated with 0.28 fewer violations. Significantly fewer violations were found at establishments in countries with more protective laws governing collective labor rights $(\beta=-$ $0.07, \mathrm{p}<0.01, \mathrm{AME}=-0.41$ ), supporting our hypothesis that domestic legal institutions influence adherence to global labor standards. ${ }^{13}$

As for the influence of civil society institutions in the audited factory's country, while we find a negative point estimate on $\log$ of INGO density as predicted, we found no evidence that activist pressure significantly predicts fewer labor violations. We do find significantly fewer violations at factories in countries with more press freedom $(\beta=-0.27, p<0.01)$. The AME indicates that a one-standard-deviation increase in the standardized press freedom variable is associated with 1.71 fewer violations, a $27 \%$ reduction from the sample mean.

Regarding market institutions in the buyer's country, significantly fewer violations were found in audits conducted on behalf of buyers from countries whose citizens have stronger prosocial attitudes $(\beta=-0.16, p<0.01)$. A one-standard-deviation increase in this standardized variable is associated with nearly one (0.99) fewer violation, a $16 \%$ reduction from the sample mean. Audits conducted on behalf of buyers in wealthier countries, as measured by $\log G P D$ per capita of buyer country, also found statistically significantly fewer violations $(\beta=-0.25, \mathrm{p}<$ 0.01). A one-standard-deviation increase is associated with 0.17 fewer violations $(\mathrm{SD} \times \mathrm{AME}=$ $0.11 \times-1.56$ ), a small effect relative to the sample mean. ${ }^{14}$ 
Turning to the controls, audits of factories in wealthier countries yielded significantly fewer violations. Significantly fewer violations were found in re-audits than in routine audits, as suspected. Significantly more violations were found at larger and more complex facilities, as proxied by greater number of auditors. The increasingly negative sequence dummies indicate that establishments' subsequent audits yield fewer violations.

Our results provide some evidence suggesting that violations recorded in audits might indeed be influenced by financial conflicts of interest and by auditor competence, as alleged by critics of supply chain auditing practices (e.g., O'Rourke 2002; Esbenshade 2004; HerasSaizarbitoria \& Boiral 2013). Specifically, audits paid for by the buyer or by a third party (the vendor, agent, or licensee) reported significantly more violations than audits paid for by the audited factory (the baseline category). Significantly more violations were found in audits conducted by more highly trained audit teams, but we found no significant influence of audit team experience. Controlling for these sources of auditor bias and competence accounts for systematic variation in auditor detection. This strengthens our ability to conclude that the coefficients on the hypothesized variables reflect the average influence of those variables on supplier factories' adherence to labor codes of conduct, unconfounded by heterogeneous auditor detection.

\section{Discussion}

\subsection{Contributions}

Our findings significantly extend the literature on transnational business regulation by revealing the institutional configurations in which supplier factories are most likely to comply with the global labor standards embodied in codes of conduct. We demonstrate that compliance rates are higher for suppliers in countries that have ratified many ILO conventions, that have 
highly protective labor regulation, and that have high levels of press freedom. We also demonstrate superior compliance among suppliers that serve buyers located in countries where consumers are wealthy and socially conscious. These findings make five important contributions to the literature.

First, by identifying roles for international, domestic, civil society, and market institutions in shaping private actors' adherence to global standards, our study provides systematic empirical support for the importance — long theorized in the literature — of multiple overlapping regulatory regimes. Among civil society institutions, we found that press freedom was a particularly important driver of supplier compliance. We suspect that this is because a free press facilitates both compliance monitoring and reputational sanctioning of noncompliance. While we found that suppliers in domestic environments saturated with INGO influence tend to have fewer violations than other suppliers, this result was not significant. This might be due to imprecise measurement of this construct or to a selection effect whereby INGOs might situate themselves in some countries with more labor problems, thereby confounding our estimate. We encourage future research to identify whether and how INGOs influence supplier adherence to global labor standards.

Second, we demonstrate the importance of state legal institutions to the efficacy of transnational business regulation. Supplier factories are more likely to meet global labor standards in states that actively participate in the ILO treaty regime and that have protective domestic labor regulation. We also show that states play an additional role in promoting adherence to global labor standards by maintaining a free press. Thus, states are important not only for exercising traditional governmental functions like lawmaking, but also for their role in enabling civil society actors such as the press to exert their own regulatory effects. These 
findings are consistent with research highlighting the ongoing importance of state-based regulatory institutions to the efficacy of transnational regulation (Seidman 2007; Büthe 2010; Vogel 2008; Bartley 2011; Locke 2013) and they present a challenge to studies predicting a diminishing role for the state in regulating the global economy (Scherer \& Palazzo 2011).

Third, we provide the first evidence linking states' treaty participation with their citizens' adherence to global norms. Although studies have attempted to establish such a connection (Hafner-Burton \& Tsutsui 2005; Lim \& Tsutsui 2012), none to our knowledge has succeeded. At a minimum, this finding indicates that a state's ILO convention ratification activity is a reliable signal of its level of labor standards. This, in turn, suggests that states have not, on average, adopted labor treaties as a smokescreen to hide poor labor practices (Hathaway 2005). Our finding does not resolve debates about the efficacy of treaties as a mechanism for shaping the behavior either of states or of private actors. The correlation we identify could result from a selection effect whereby states adopt only treaties that contain obligations their citizens already meet (Goldsmith \& Posner 2005; Hathaway 2005) or a treatment effect whereby treaty ratification sparks the diffusion of norms (Chayes \& Chayes 1995; Börzel \& Risse 2010; Abbott \& Snidal 2012), the implementation of international obligations through domestic law (Simmons 2009), or some combination of these mechanisms. While our analysis cannot identify the particular mechanisms that drive the relationship between state treaty ratification and private actor adherence to global labor norms, our finding is an important step in the development of the literature on global norm diffusion through international law and IGOs.

Fourth, we offer the first empirical evidence for an association between market pressures on MNCs and working conditions in their foreign supply chains. Studies that have investigated how activism affects labor outcomes have focused on pressure targeted directly at suppliers, not 
at their multinational buyers (Harrison \& Scorse 2010). Although research on private politics has revealed how stakeholder pressure on MNCs can encourage them to adopt codes of conduct and other CSR activities (Reid \& Toffel 2009; Fransen 2012), we are not aware of any studies that assess whether these companies effectively implement the measures they adopt. Similarly, although studies have demonstrated how activist tactics such as shaming and boycotts affect an MNC's bottom line (King \& Soule 2007; Vasi \& King 2012), we are not aware of any that establish a connection between such institutional pressures on MNCs and labor conditions at their overseas suppliers.

This finding may be in tension with prior research demonstrating that trade with developed-country MNCs raises labor standards in developing countries only when those MNCs directly own their foreign suppliers and not when they outsource production in arms-length transactions (Mosley 2011a). One possible explanation for this discrepancy is that Mosley (2011a) measures labor standards at the state level, whereas we measure them at individual supplier firms. It is possible that while, as Mosley (2011a) argues, economic and political pressures may drive developing states to adopt lax labor policies in order to attract outsourcing business, individual suppliers that subcontract with MNCs serving wealthy and socially conscious consumers may nonetheless feel private market pressure to maintain higher standards. Our study thus highlights the importance of measuring firm-level adherence to global labor standards - as well as state-level adoption of global labor standards - to fully assess the impact of transnational regulation.

Finally, although our study does not test the effects of codes of conduct and social auditing as mechanisms for inducing adherence to global labor standards, it demonstrates that these practices are enmeshed in a web of regulatory institutions that independently influence 
compliance. Our findings strongly suggest that corporate codes of conduct should not be viewed as "single-actor schemes" (Abbott \& Snidal 2009: 47), but rather as dependent on these other regulatory institutions. Future research is necessary to determine what regulatory effects, if any, codes and monitoring independently contribute to the mix.

\subsection{Limitations}

We acknowledge several limitations of our study and suggest additional avenues for future research. First, while our study has theorized and tested the influence of key macroinstitutional conditions on supplier factories' adherence to global labor standards, our methodology cannot identify the precise mechanisms by which these institutional factors influence private actors or interact with one another. We encourage future research to investigate the social processes underlying the associations we identify.

Second, our findings are subject to several data limitations. For instance, our data come from a single social auditing firm and measure compliance only by supplier factories subject to codes of conduct and social auditing imposed by their buyers. Because so many global buyers impose codes and monitoring, we believe our sample is broadly representative of a highly significant segment of global producers, but these characteristics of our data may limit the degree to which our findings apply to factories that do not serve global buyers or whose global buyers do not privately impose labor standards. We note that although our sample variation is limited on these dimensions, it varies across countries, industries, and multinational buyers-important dimensions lacking in similar studies. We encourage future research to test the generalizability of our findings. Our study is also limited by our decision to omit certain categories of violations from our analysis in order to enhance the reliability of our measure. Future research is necessary to determine if the institutions that shape adherence to the code provisions we analyzed likewise 
shape adherence to code provisions concerning other labor standards like freedom of association. In addition, due to data limitations, our study does not include all the variables found by prior studies to predict regulatory compliance. For instance, we lack data on firm size and regulatory enforcement practices. We have attempted to identify reasonable proxies for key independent variables, as described in our methodology section above. However, we cannot rule out the possibility that unobserved variables influence levels of adherence to global labor standards.

\section{Conclusion}

This research reveals the importance of state, civil society, and market governance institutions in shaping adherence to global labor standards. We demonstrate that supplier factories are more likely to adhere to global labor standards when they are located in states that participate actively in the ILO treaty regime and that maintain highly protective labor regulation and high levels of press freedom. We further demonstrate that supplier-factory compliance is associated not only with institutions in the supplier's home country, but also with institutions in the global buyer's home country: Suppliers are more compliant with global labor standards when they serve buyers located in countries where consumers are wealthy and socially conscious. Taken together, these findings point the way toward building more effective transnational regulatory regimes. 


\section{References}

Abbott, K., \& Snidal, D. 2009. The governance triangle: Regulatory standards institutions and the shadow of the state. In W. Mattli \& N. Woods (Eds.), The Politics of Global Regulation: 44-88. Princeton, NJ: Princeton University Press.

Abbott, K., \& Snidal, D. 2012. Taking responsive regulation transnational. Regulation \& Governance 7(1): 95-113.

Amengual, M. 2010. Complementary labor regulation: The uncoordinated combination of state and private regulators in the Dominican Republic. World Development 38(3): 405-414.

Ang, D., Brown, D., Dehejia, R., \& Robertson, R. 2012. Public disclosure, reputation sensitivity, and labor law compliance: Evidence from Better Factories Cambodia. Review of Development Economics 16(4): 594-607.

Ayres, I., \& Braithwaite, J. 1992. Responsive Regulation: Transcending the Deregulation Debate. New York: Oxford University Press.

Bardach, E., \& Kagan, R. A. 1982/2002. Going by the Book: The Problem of Regulatory Unreasonableness. New Brunswick, NJ: Transaction.

Bartley, T. 2011. Transnational governance as the layering of rules: Intersections of public and private standards. Theoretical Inquiries in Law 12(2): 517-542.

Berliner, D., \& Prakash, A. 2013. Signaling environmental stewardship in the shadow of weak governance: The global diffusion of ISO 14001. Law \& Society Review 47(2): 345-373.

Börzel, T. A., \& Risse, T. 2010. Governance without a state: Can it work? Regulation \& Governance 4(2): 113-134.

Braithwaite, J., \& Drahos, P. 2000. Global Business Regulation. Cambridge, UK: Cambridge University Press.

Büthe, T. 2010. Global private politics: A research agenda. Business and Politics 12(3): Article 12.

Cameron, A. C., Gelbach, J. B., \& Miller, D. L. 2011. Robust inference with multiway clustering. Journal of Business \& Economic Statistics 29(2): 238-249.

Campbell, J. 2007. Why would corporations behave in socially responsible ways? An institutional theory of corporate social responsibility. Academy of Management Review 32(3): 946-967.

Chayes, A., \& Chayes, A. 1995. The New Sovereignty: Compliance with International Regulatory Agreements. Cambridge, MA: Harvard University Press. 
Coslovsky, S. V., \& Locke, R. 2013. Parallel paths to enforcement: Private compliance, public regulation, and labor standards in the Brazilian sugar sector. Politics \& Society 41(4): 497526.

Devinney, T. M., Auger, P., \& Eckhardt, G. M. 2010. The Myth of the Ethical Consumer. Cambridge, UK: Cambridge University Press.

Dyck, A., Volchkova, N., \& Zingales, L. 2008. Corporate governance role of the media: Evidence from Russia. Journal of Finance 63(3): 1093-1136.

Eberlein, B., Abbott, K. W., Black, J., Meidinger, E., \& Wood, S. 2014. Transnational business governance interactions: Conceptualization and framework for analysis. Regulation \& Governance 8(1): 1-21.

Esbenshade, J. L. 2004. Monitoring Sweatshops: Workers, Consumers, and the Global Apparel Industry. Philadelphia: Temple University Press.

Fransen, L. 2012. Corporate Social Responsibility and Global Labor Standards: Firms and Activists in the Making of Private Regulation. New York: Routledge.

Fung, A., O'Rourke, D., \& Sabel, C. 2001. Can We Put an End to Sweatshops? Boston: Beacon.

Goldsmith, J. L., \& Posner, E. A. 2005. The Limits of International Law. Oxford, UK: Oxford University Press.

Greenhill, B. 2010. The company you keep: International socialization and the diffusion of human rights norms. International Studies Quarterly 54(1): 127-145.

Greenhill, B., Mosley, L., \& Prakash, A. 2009. Trade-based diffusion of labor rights: A panel study, 1986-2002. American Political Science Review 103(4): 669-690.

Hafner-Burton, E. M., \& Tsutsui, K. 2005. Human rights in a globalizing world: The paradox of empty promises. American Journal of Sociology 110(5): 1373-1411.

Hainmueller, J., Hiscox, M. J., \& Sequeira, S. Forthcoming. Consumer demand for the Fair Trade label: Evidence from a multi-store field experiment. Review of Economics and Statistics.

Harrison, A., \& Scorse, J. 2010. Multinationals and anti-sweatshop activism. American Economic Review 100(1): 247-273.

Hathaway, O. A. 2005. Between power and principle: An integrated theory of international law. University of Chicago Law Review 72(2): 469-536.

Heras-Saizarbitoria, I., \& Boiral, O. 2013. ISO 9001 and ISO 14001: Towards a research agenda on management system standards. International Journal of Management Reviews 15(1): 4765. 
Keck, M. E., \& Sikkink, K. 1998. Activists Beyond Borders. Ithaca, NY: Cornell University Press.

King, A., \& M. W. Toffel. 2009. Self-regulatory institutions for solving environmental problems: Perspectives and contributions from the management literature. In M. Delmas and O. Young (Eds.), Governing the Environment: Interdisciplinary Perspectives: 98-115. Cambridge, UK: Cambridge University Press.

King, B. G., \& Soule, S. A. 2007. Social movements as extra-institutional entrepreneurs: The effect of protest on stock price returns. Administrative Science Quarterly 52(3): 413-442.

Kocer, G. R., \& Fransen, L. 2009. Codes of conduct and the promise of a change of climate in worker organization. European Journal of Industrial Relations 15(3): 237-256.

Lenox, M., \& Eesley, C. 2009. Private environmental activism and the selection and response of firm targets. Journal of Economics and Management Strategy 18(1): 45-73.

Lim, A., \& Tsutsui, K. 2012. Globalization and commitment in corporate social responsibility: Cross-national analyses of institutional and political-economy effects. American Sociological Review 77(1): 69-98.

Linos, K. 2007. How can international organizations shape national welfare states? Evidence from compliance with European Union directives. Comparative Political Studies 40(5): 547570 .

Locke, R. M., Qin, F., \& Brause, A. 2007. Does monitoring improve labor standards? Lessons from Nike. Industrial and Labor Relations Review 61(1): 3-31.

Locke, R. M. 2013. The Promise and Limits of Private Power: Promoting Labor Standards in a Global Economy. New York: Cambridge University Press.

Locke, R. M., Rissing, B. A., \& Pal, T. 2013. Complements or substitutes? Private codes, state regulation and the improvement of labor standards in global supply chains. British Journal of Industrial Relations 51(3): 519-552.

Locke, R. M., \& Romis, M. 2007. Improving work conditions in a global supply chain. MIT Sloan Management Review 48(2): 54-62.

Marx, A. 2008. Limits to non-state market regulation: A qualitative comparative analysis of the international sport footwear industry and the Fair Labor Association. Regulation \& Governance 2(2): 253-273.

Mattli, W., \& Woods, N. 2009. In whose benefit? Explaining regulatory change in global politics. In W. Mattli \& N. Woods (Eds.), The Politics of Global Regulation: 1-43. Princeton, NJ: Princeton University Press.

McBarnet, D. J., \& Kurkchiyan, M. 2007. Contractual control: Global supply chains and "other regulation." In D. McBarnet, A. Voiculescu, and T. Campbell (Eds.), The New Corporate 
Accountability: Corporate Social Responsibility and the Law: 59-92. Cambridge, UK: Cambridge University Press.

Mosley, L. 2011a. Labor Rights and Multinational Production. New York: Cambridge University Press.

Mosley, L. 2011b. Replication data for Collective Labor Rights Dataset. http://hdl.handle.net/1902.1/15590. L. Mosley [Distributor] V1 [Version].

Oka, C. 2010a. Accounting for the gaps in labour standard compliance: The role of reputationconscious buyers in the Cambodian garment industry. European Journal of Development Research 22(1): 59-78.

Oka, C. 2010b. Channels of buyer influence and labor standard compliance: The case of Cambodia's garment sector. Advances in Industrial and Labor Relations 17: 153-183.

O'Rourke, D. 2002. Monitoring the monitors: A critique of corporate third-party labor monitoring. In R. Jenkins, R. Pearson, \& G. Seyfang (Eds.), Corporate Responsibility and Labour Rights: Codes of Conduct in the Global Economy: 196-207. London: Earthscan.

Reid, E. M., \& Toffel, M. W. 2009. Responding to public and private politics: Corporate disclosure of climate change strategies. Strategic Management Journal 30(11): 1157-1178.

Rodríguez-Garavito, C. 2005. Global governance and labor rights: Codes of conduct and antisweatshop struggles in global apparel factories in Mexico and Guatemala. Politics \& Society 33(2): 203-233.

Scherer, A. G., \& Palazzo, G. 2011. The new political role of business in a globalized world: A review of a new perspective on CSR and its implications for the firm, governance, and democracy. Journal of Management Studies 48(4): 899-931.

Scott, C. 2012. Non-judicial enforcement of transnational private regulation. In F. Cafaggi (Ed.), Enforcement of Transnational Regulation: Ensuring Compliance in a Global World: 147164. Northampton, MA: Edward Elgar.

Seidman, G. 2007. Beyond the Boycott: Labor Rights, Human Rights, and Transnational Activism. New York: Russell Sage Foundation.

Shamir, R. 2005. Corporate social responsibility: A case of hegemony and counter-hegemony. In B. de Sousa Santos \& C. A. Rodríguez-Garavito (Eds.), Law and Globalization from Below: 92-117. Cambridge, UK: Cambridge University Press.

Short, J. L., \& Toffel, M. W. 2008. Coerced confessions: Self-policing in the shadow of the regulator. Journal of Law, Economics \& Organization 24(1): 45-71.

Short, J. L., \& Toffel, M. W. 2010. Making self-regulation more than merely symbolic: The critical role of the legal environment. Administrative Science Quarterly 55: 361-396. 
Simmons, B. A. 2009. Mobilizing for Human Rights: International Law in Domestic Politics. Cambridge, UK: Cambridge University Press.

Snow, D. A., Rochford, E. B., Jr., Worden, S. K., \& Benford, R. D. 1986. Frame alignment processes, micromobilization, and movement participation. American Sociological Review 51(4): 464-481.

Soule, S. 2009. Contention and Corporate Social Responsibility. New York: Cambridge University Press.

Tsogas, G. 2001. Labor Regulation in a Global Economy. Armonk, NY: M.E. Sharpe.

Union of International Associations. 2004-2009. Yearbook of International Organizations, various issues. München: KG Saur Verlag.

Vasi, I. B., \& King, B. G. 2012. Social movements, risk perceptions, and economic outcomes: The effect of primary and secondary stakeholder activism on firms' perceived environmental risk and financial performance. American Sociological Review 77(4): 573-596.

Vogel, D. 2008. Private global business regulation. Annual Review of Political Science 11: 261282.

Zald, M. N. 1996. Culture, ideology, and strategic framing. In D. McAdam, J. D. McCarthy, \& M. N. Zald (Eds.), Comparative Perspectives on Social Movements: Political Opportunities, Mobilizing Structures, and Cultural Framings: 261-274. Cambridge, UK: Cambridge University Press. 
Table 1. Audits by factory location (47 countries)

\begin{tabular}{lrr}
\hline Africa (9 countries) & $\mathbf{4 9 6}$ & \\
Americas (12 countries) & $\mathbf{5 , 2 9 3}$ & \\
$\quad$ United States & & 3,131 \\
Mexico & & 941 \\
Brazil & & 277 \\
Other & $\mathbf{3 7 , 3 5 3}$ & 944 \\
Asia $(15$ countries) & & 28,281 \\
China (including Hong Kong \& Macau) & & 2,029 \\
India & & 1,458 \\
Bangladesh & & 1,297 \\
Vietnam & & 941 \\
Indonesia & & 642 \\
Thailand & & 630 \\
Philippines & & 483 \\
South Korea & & 428 \\
Pakistan & & 378 \\
Sri Lanka & & 786 \\
Other & $\mathbf{1 , 2 4 1}$ & \\
Europe (11 countries) & & 480 \\
Turkey & & 335 \\
Italy & & 426 \\
$\quad$ Other & \\
\hline Total & & \\
\hline
\end{tabular}

Table 2. Industry composition

\begin{tabular}{lrrrr}
\hline \multicolumn{1}{c}{ Industry } & \multicolumn{1}{c}{ Audits } & \multicolumn{3}{c}{ Establishments } \\
\hline Accessories & 4,183 & $9 \%$ & 1,902 & $9 \%$ \\
Building materials & 863 & $2 \%$ & 371 & $2 \%$ \\
Chemicals and plastics & 421 & $1 \%$ & 243 & $1 \%$ \\
Electronics & 1,475 & $3 \%$ & 578 & $3 \%$ \\
Food, agriculture, beverage & 887 & $2 \%$ & 559 & $3 \%$ \\
Footwear & 803 & $2 \%$ & 349 & $2 \%$ \\
Furniture & 820 & $2 \%$ & 362 & $2 \%$ \\
Garments & 14,099 & $32 \%$ & 6,238 & $29 \%$ \\
Metal products & 455 & $1 \%$ & 194 & $1 \%$ \\
Paper, printing, publishing & 791 & $2 \%$ & 466 & $2 \%$ \\
Services & 172 & $0 \%$ & 107 & $0 \%$ \\
Toys & 796 & $2 \%$ & 334 & $2 \%$ \\
Undetermined & 18,618 & $42 \%$ & 10,133 & $46 \%$ \\
\hline Total & $\mathbf{4 4 , 3 8 3}$ & $\mathbf{1 0 0 \%}$ & $\mathbf{2 1 , 8 3 6}$ & $\mathbf{1 0 0 \%}$ \\
\hline
\end{tabular}


Table 3. Descriptive statistics

Panel A. Summary statistics

\begin{tabular}{lrccc}
\hline Variable & Mean & SD & Min & Max \\
\hline Labor violations & 6.38 & 5.89 & 0 & 25 \\
Labor treaties $(\log +1)$ & 3.30 & 0.38 & 0.69 & 4.88 \\
Labor treaties $(\log +1) \diamond$ & 0.00 & 1.00 & -6.92 & 4.19 \\
Labor laws & -0.91 & 0.50 & -2.96 & 1.19 \\
Labor laws $\diamond$ & 0.00 & 1.00 & -4.08 & 4.20 \\
INGO density $(\log )$ & 1.06 & 1.26 & 0.22 & 6.46 \\
INGO density $(\log ) \diamond$ & 0.00 & 1.00 & -0.67 & 4.27 \\
Press freedom & 0.37 & 0.28 & 0.12 & 0.98 \\
Press freedom $\diamond$ & 0.00 & 1.00 & -0.9 & 2.18 \\
Prosocial attitude in buyer country & -0.67 & 0.37 & -1.44 & 1.33 \\
Prosocial attitude in buyer country $\diamond$ & 0.00 & 1.00 & -2.08 & 5.35 \\
GDP per capita of buyer country $(\log )$ & 10.62 & 0.11 & 6.61 & 10.68 \\
GDP per capita $(\log )$ & 7.88 & 1.05 & 5.69 & 10.68 \\
OECD member & 0.14 & 0.35 & 0 & 1 \\
Re-audit & 0.32 & 0.47 & 0 & 1 \\
Third-party audit protocol & 0.12 & 0.32 & 0 & 1 \\
Number of auditors & 1.82 & 0.63 & 0 & 7 \\
Audit paid by buyer & 0.48 & 0.50 & 0 & 1 \\
Audit paid by vendor, agent, or licensee & 0.39 & 0.49 & 0 & 1 \\
Audit paid by unknown & 0.09 & 0.29 & 0 & 1 \\
Audit team tenure & 4.93 & 1.98 & 0 & 15 \\
Audit skills training & 1.79 & 1.51 & 0 & 14 \\
Audit sequence & 2.12 & 1.48 & 1 & 6 \\
\hline N & &
\end{tabular}

$\mathrm{N}=44,383$ audits except 21,708 for audit team tenure and 21,967 for audit skills training.

$\diamond$ indicates standardized variable.

\section{Panel B. Correlations}

(1) Labor violations

(2) Labor treaties $(\log +1)$

(3) Labor laws

(4) INGO density $(\log )$

(5) Press freedom

(6) Prosocial attitude in buyer country

(7) GDP per capita of buyer country (log)

(8) GDP per capita $(\log )$

(9) OECD member

(10) Re-audit

(11) Third-party audit protocol

(12) Number of auditors

(13) Audit paid by buyer

(14) Audit paid by vendor, agent, or licensee

(15) Audit team tenure

(16) Audit skills training

(17) Audit sequence
(1)

1.00

$-0.06 \quad 1.00$

$\begin{array}{lll}-0.02 & -0.20 & 1.00\end{array}$

$\begin{array}{llll}-0.24 & 0.30 & -0.09 & 1.00\end{array}$

$\begin{array}{lllll}-0.27 & 0.19 & -0.11 & 0.81 & 1.00\end{array}$

$\begin{array}{lllllll}-0.20 & -0.02 & 0.06 & 0.17 & 0.15 & 1.00\end{array}$

$\begin{array}{lllllll}-0.13 & 0.00 & 0.05 & 0.09 & 0.08 & 0.58 & 1.00\end{array}$

$\begin{array}{llllllll}-0.19 & -0.11 & 0.42 & 0.47 & 0.54 & 0.13 & 0.11 & 1.00\end{array}$

$\begin{array}{lllllllll}-0.20 & 0.10 & 0.21 & 0.63 & 0.71 & 0.14 & 0.10 & 0.85 & 1.00\end{array}$

$\begin{array}{llllllllll}-0.16 & -0.02 & -0.02 & -0.16 & -0.18 & -0.21 & -0.14 & -0.11 & -0.14 & 1.00\end{array}$

$\begin{array}{lllllllllll}0.09 & -0.01 & 0.00 & -0.16 & -0.15 & -0.75 & -0.51 & -0.07 & -0.13 & 0.26 & 1.00\end{array}$

$\begin{array}{llllllllllll}0.12 & -0.13 & 0.07 & -0.31 & -0.28 & -0.09 & -0.04 & -0.12 & -0.19 & 0.06 & 0.09 & 1.00\end{array}$

$\begin{array}{lllllllllllll}0.08 & -0.02 & -0.02 & 0.03 & 0.05 & -0.44 & -0.27 & 0.03 & 0.03 & 0.05 & 0.33 & -0.02 & 1.00\end{array}$

$\begin{array}{llllllllllllll}-0.03 & -0.03 & 0.00 & -0.11 & -0.15 & 0.35 & 0.26 & -0.12 & -0.14 & -0.03 & -0.28 & 0.01 & -0.77 & 1.00\end{array}$



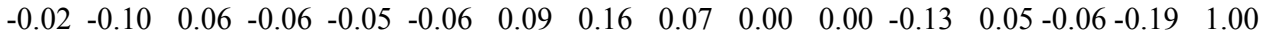

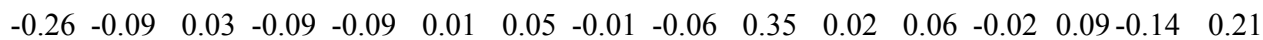

$\mathrm{N}=44,383$ audits. 
Table 4. Regression results

Dependent variable: Labor violations

\begin{tabular}{|c|c|c|c|c|c|c|}
\hline \multirow{3}{*}{ Specification notes: } & \multirow{2}{*}{\multicolumn{2}{|c|}{$\begin{array}{c}\text { Primary model } \\
\text { (1) }\end{array}$}} & \multicolumn{4}{|c|}{ Robustness tests } \\
\hline & & & \multirow{2}{*}{$\begin{array}{c}\text { (2) } \\
\text { Dependent } \\
\text { variable not } \\
\text { winsorized }\end{array}$} & \multirow[b]{2}{*}{$\begin{array}{c}(3) \\
\text { Alternative } \\
\text { measure of } \\
\text { prosocial } \\
\text { attitude } \\
\text { (Note 1) }\end{array}$} & \multirow{2}{*}{$\begin{array}{c}\text { (4) } \\
\text { Imputed } \\
\text { industry }\end{array}$} & \multirow[b]{2}{*}{$\begin{array}{c}(5) \\
\text { Standard } \\
\text { errors } \\
\text { clustered two } \\
\text { ways } \\
\text { (Note 2) } \\
\text { Coef }\end{array}$} \\
\hline & Coef & AME & & & & \\
\hline \multicolumn{7}{|l|}{ Hypothesized variables } \\
\hline \multicolumn{7}{|l|}{ Audited establishment country-year variables } \\
\hline Labor treaties $(\log +1) \diamond$ & $\begin{array}{l}-0.043+ \\
{[0.024]}\end{array}$ & -0.28 & $\begin{array}{l}-0.043+ \\
{[0.024]}\end{array}$ & $\begin{array}{l}-0.043+ \\
{[0.024]}\end{array}$ & $\begin{array}{l}-0.041+ \\
{[0.023]}\end{array}$ & $\begin{array}{l}-0.043+ \\
{[0.024]}\end{array}$ \\
\hline Labor laws $\diamond$ & $\begin{array}{l}-0.065^{* *} \\
{[0.023]}\end{array}$ & -0.41 & $\begin{array}{l}-0.065^{* *} \\
{[0.023]}\end{array}$ & $\begin{array}{l}-0.065^{* *} \\
{[0.022]}\end{array}$ & $\begin{array}{l}-0.064 * * \\
{[0.023]}\end{array}$ & $\begin{array}{l}-0.065^{* *} \\
{[0.023]}\end{array}$ \\
\hline INGO density $(\log ) \diamond$ & $\begin{array}{l}-0.034 \\
{[0.030]}\end{array}$ & -0.21 & $\begin{array}{l}-0.034 \\
{[0.030]}\end{array}$ & $\begin{array}{l}-0.034 \\
{[0.029]}\end{array}$ & $\begin{array}{l}-0.032 \\
{[0.030]}\end{array}$ & $\begin{array}{l}-0.034 \\
{[0.030]}\end{array}$ \\
\hline Press freedom $\diamond$ & $\begin{array}{l}-0.268 * * \\
{[0.038]}\end{array}$ & -1.71 & $\begin{array}{l}-0.269^{* *} \\
{[0.039]}\end{array}$ & $\begin{array}{l}-0.265^{* *} \\
{[0.038]}\end{array}$ & $\begin{array}{l}-0.261 * * \\
{[0.038]}\end{array}$ & $\begin{array}{l}-0.268 * * \\
{[0.040]}\end{array}$ \\
\hline \multicolumn{7}{|l|}{ Buyer country-year variables } \\
\hline Prosocial attitude in buyer country $\diamond$ & $\begin{array}{l}-0.155^{* *} \\
{[0.015]}\end{array}$ & -0.99 & $\begin{array}{l}-0.155^{* *} \\
{[0.015]}\end{array}$ & $\begin{array}{l}-0.185^{* *} \\
{[0.014]}\end{array}$ & $\begin{array}{l}-0.153 * * \\
{[0.014]}\end{array}$ & $\begin{array}{l}-0.155 * * \\
{[0.030]}\end{array}$ \\
\hline GDP per capita of buyer country (log) & $\begin{array}{l}-0.246^{* *} \\
{[0.088]}\end{array}$ & -1.56 & $\begin{array}{l}-0.249 * * \\
{[0.090]}\end{array}$ & $\begin{array}{l}-0.014 \\
{[0.105]}\end{array}$ & $\begin{array}{l}-0.239 * * \\
{[0.084]}\end{array}$ & $\begin{array}{l}-0.246 \\
{[0.150]}\end{array}$ \\
\hline \multicolumn{7}{|l|}{ Control variables } \\
\hline GDP per capita (log) & $\begin{array}{l}-0.079 * \\
{[0.031]}\end{array}$ & -0.50 & $\begin{array}{l}-0.079 * \\
{[0.031]}\end{array}$ & $\begin{array}{l}-0.075^{*} \\
{[0.031]}\end{array}$ & $\begin{array}{l}-0.081 * \\
{[0.032]}\end{array}$ & $\begin{array}{l}-0.079^{*} \\
{[0.038]}\end{array}$ \\
\hline OECD member & $\begin{array}{c}0.165 \\
{[0.132]}\end{array}$ & 1.05 & $\begin{array}{c}0.165 \\
{[0.132]}\end{array}$ & $\begin{array}{c}0.159 \\
{[0.130]}\end{array}$ & $\begin{array}{c}0.169 \\
{[0.131]}\end{array}$ & $\begin{array}{c}0.165 \\
{[0.134]}\end{array}$ \\
\hline \multicolumn{7}{|l|}{ Audit variables } \\
\hline Re-audit & $\begin{array}{l}-0.172 * * \\
{[0.015]}\end{array}$ & -1.10 & $\begin{array}{l}-0.173 * * \\
{[0.015]}\end{array}$ & $\begin{array}{l}-0.173 * * \\
{[0.015]}\end{array}$ & $\begin{array}{l}-0.178 * * \\
{[0.015]}\end{array}$ & $\begin{array}{l}-0.172 * * \\
{[0.035]}\end{array}$ \\
\hline Third-party audit protocol & $\begin{array}{l}-0.067^{*} \\
{[0.032]}\end{array}$ & -0.43 & $\begin{array}{l}-0.067^{*} \\
{[0.032]}\end{array}$ & $\begin{array}{l}-0.102 * * \\
{[0.037]}\end{array}$ & $\begin{array}{l}-0.083 * * \\
{[0.032]}\end{array}$ & $\begin{array}{l}-0.067 \\
{[0.055]}\end{array}$ \\
\hline Number of auditors & $\begin{array}{l}0.101 * * \\
{[0.022]}\end{array}$ & 0.64 & $\begin{array}{l}0.100^{* *} \\
{[0.022]}\end{array}$ & $\begin{array}{c}0.100^{* *} \\
{[0.022]}\end{array}$ & $\begin{array}{l}0.095^{* *} \\
{[0.022]}\end{array}$ & $\begin{array}{l}0.101 * * \\
{[0.024]}\end{array}$ \\
\hline Audit paid by buyer & $\begin{array}{l}0.307 * * \\
{[0.029]}\end{array}$ & 1.95 & $\begin{array}{l}0.308^{* *} \\
{[0.030]}\end{array}$ & $\begin{array}{l}0.301 * * \\
{[0.029]}\end{array}$ & $\begin{array}{l}0.304 * * \\
{[0.026]}\end{array}$ & $\begin{array}{c}0.307 * * \\
{[0.042]}\end{array}$ \\
\hline Audit paid by vendor, agent, or licensee & $\begin{array}{l}0.280^{* *} \\
{[0.039]}\end{array}$ & 1.79 & $\begin{array}{l}0.281 * * \\
{[0.039]}\end{array}$ & $\begin{array}{l}0.279^{* *} \\
{[0.041]}\end{array}$ & $\begin{array}{l}0.258 * * \\
{[0.036]}\end{array}$ & $\begin{array}{l}0.280^{* *} \\
{[0.050]}\end{array}$ \\
\hline Audit team tenure (average) & $\begin{array}{l}-0.013 \\
{[0.012]}\end{array}$ & -0.08 & $\begin{array}{l}-0.013 \\
{[0.012]}\end{array}$ & $\begin{array}{l}-0.013 \\
{[0.012]}\end{array}$ & $\begin{array}{l}-0.013 \\
{[0.011]}\end{array}$ & $\begin{array}{l}-0.013 \\
{[0.014]}\end{array}$ \\
\hline Audit skills training (average) & $\begin{array}{c}0.030 * * \\
{[0.009]}\end{array}$ & 0.19 & $\begin{array}{l}0.030 * * \\
{[0.009]}\end{array}$ & $\begin{array}{l}0.029 * * \\
{[0.009]}\end{array}$ & $\begin{array}{l}0.030 * * \\
{[0.009]}\end{array}$ & $\begin{array}{c}0.030^{*} \\
{[0.013]}\end{array}$ \\
\hline Factory's second inspection & $\begin{array}{l}-0.320^{* *} \\
{[0.040]}\end{array}$ & -2.04 & $\begin{array}{l}-0.323 * * \\
{[0.041]}\end{array}$ & $\begin{array}{l}-0.319^{* *} \\
{[0.039]}\end{array}$ & $\begin{array}{l}-0.321 * * \\
{[0.041]}\end{array}$ & $\begin{array}{l}-0.320^{* *} \\
{[0.041]}\end{array}$ \\
\hline Factory's third inspection & $\begin{array}{l}-0.534 * * \\
{[0.058]}\end{array}$ & -3.40 & $\begin{array}{l}-0.538^{* *} \\
{[0.059]}\end{array}$ & $\begin{array}{l}-0.532 * * \\
{[0.057]}\end{array}$ & $\begin{array}{l}-0.536^{* *} \\
{[0.059]}\end{array}$ & $\begin{array}{l}-0.534 * * \\
{[0.067]}\end{array}$ \\
\hline Factory's fourth inspection & $\begin{array}{l}-0.568^{* *} \\
{[0.072]}\end{array}$ & -3.62 & $\begin{array}{l}-0.572 * * \\
{[0.073]}\end{array}$ & $\begin{array}{l}-0.566^{* *} \\
{[0.071]}\end{array}$ & $\begin{array}{l}-0.571 * * \\
{[0.073]}\end{array}$ & $\begin{array}{l}-0.568 * * \\
{[0.073]}\end{array}$ \\
\hline Factory's fifth inspection & $\begin{array}{l}-0.637 * * \\
{[0.101]}\end{array}$ & -4.06 & $\begin{array}{l}-0.641 * * \\
{[0.102]}\end{array}$ & $\begin{array}{l}-0.634^{* *} \\
{[0.101]}\end{array}$ & $\begin{array}{l}-0.640 * * \\
{[0.103]}\end{array}$ & $\begin{array}{l}-0.637 * * \\
{[0.108]}\end{array}$ \\
\hline Factory's sixth or higher inspection & $\begin{array}{l}-0.675^{* *} \\
{[0.125]}\end{array}$ & -4.30 & $\begin{array}{l}-0.679 * * \\
{[0.127]}\end{array}$ & $\begin{array}{l}-0.671^{* *} \\
{[0.124]}\end{array}$ & $\begin{array}{l}-0.682 * * \\
{[0.129]}\end{array}$ & $\begin{array}{l}-0.675 * * \\
{[0.130]}\end{array}$ \\
\hline Year 2005 & $\begin{array}{c}0.039 \\
{[0.055]}\end{array}$ & 0.25 & $\begin{array}{c}0.038 \\
{[0.055]}\end{array}$ & $\begin{array}{c}0.048 \\
{[0.052]}\end{array}$ & $\begin{array}{c}0.040 \\
{[0.054]}\end{array}$ & $\begin{array}{c}0.039 \\
{[0.072]}\end{array}$ \\
\hline Year 2006 & $\begin{array}{l}-0.007 \\
{[0.072]}\end{array}$ & -0.04 & $\begin{array}{l}-0.006 \\
{[0.073]}\end{array}$ & $\begin{array}{c}0.002 \\
{[0.068]}\end{array}$ & $\begin{array}{l}-0.003 \\
{[0.072]}\end{array}$ & $\begin{array}{l}-0.007 \\
{[0.092]}\end{array}$ \\
\hline Year 2007 & $\begin{array}{l}-0.075 \\
{[0.108]}\end{array}$ & -0.48 & $\begin{array}{l}-0.074 \\
{[0.109]}\end{array}$ & $\begin{array}{l}-0.073 \\
{[0.103]}\end{array}$ & $\begin{array}{l}-0.070 \\
{[0.106]}\end{array}$ & $\begin{array}{l}-0.075 \\
{[0.118]}\end{array}$ \\
\hline Year 2008 & $\begin{array}{l}-0.151 \\
{[0.093]}\end{array}$ & -0.96 & $\begin{array}{l}-0.150 \\
{[0.093]}\end{array}$ & $\begin{array}{l}-0.148+ \\
{[0.090]}\end{array}$ & $\begin{array}{l}-0.146 \\
{[0.090]}\end{array}$ & $\begin{array}{l}-0.151 \\
{[0.120]}\end{array}$ \\
\hline Year 2009 & $\begin{array}{l}-0.337 * * \\
{[0.073]}\end{array}$ & -2.15 & $\begin{array}{l}-0.338^{* *} \\
{[0.073]}\end{array}$ & $\begin{array}{l}-0.325^{* *} \\
{[0.074]}\end{array}$ & $\begin{array}{l}-0.330 * * \\
{[0.072]}\end{array}$ & $\begin{array}{l}-0.337 * * \\
{[0.084]}\end{array}$ \\
\hline Audited establishment industries & & & & & & \\
\hline Accessories industry & $\begin{array}{c}0.093 * * \\
{[0.024]}\end{array}$ & 0.59 & $\begin{array}{c}0.094 * * \\
{[0.024]}\end{array}$ & $\begin{array}{c}0.092 * * \\
{[0.024]}\end{array}$ & $\begin{array}{c}0.124 * * \\
{[0.016]}\end{array}$ & $\begin{array}{c}0.093 * * \\
{[0.026]}\end{array}$ \\
\hline
\end{tabular}


Building materials industry

Chemicals and plastics industry

Electronics industry

Food, agriculture, and beverage industry

Footwear industry

Furniture industry

Metal products industry

Paper, printing, and publishing industry

Services industry

Toys industry

\begin{tabular}{cccccc}
$0.212^{* *}$ & 1.35 & $0.214^{* *}$ & $0.215^{* *}$ & $0.225^{* *}$ & $0.212^{* *}$ \\
{$[0.038]$} & & {$[0.038]$} & {$[0.038]$} & {$[0.027]$} & {$[0.060]$} \\
0.099 & 0.63 & 0.098 & 0.102 & 0.076 & 0.099 \\
{$[0.099]$} & & {$[0.099]$} & {$[0.100]$} & {$[0.055]$} & {$[0.156]$} \\
$0.084^{*}$ & 0.53 & $0.082^{*}$ & $0.083^{*}$ & $0.157^{* *}$ & $0.084+$ \\
{$[0.038]$} & & {$[0.039]$} & {$[0.039]$} & {$[0.023]$} & {$[0.049]$} \\
0.018 & 0.11 & 0.019 & 0.026 & -0.078 & 0.018 \\
{$[0.055]$} & & {$[0.055]$} & {$[0.057]$} & {$[0.053]$} & {$[0.058]$} \\
$0.164 * *$ & 1.04 & $0.163^{* *}$ & $0.166^{* *}$ & $0.183^{* *}$ & $0.164^{* *}$ \\
{$[0.032]$} & & {$[0.032]$} & {$[0.033]$} & {$[0.024]$} & {$[0.034]$} \\
$0.345^{* *}$ & 2.20 & $0.347^{* *}$ & $0.347^{* *}$ & $0.373^{* *}$ & $0.345^{* *}$ \\
{$[0.050]$} & & {$[0.050]$} & {$[0.050]$} & {$[0.034]$} & {$[0.073]$} \\
$0.170^{* *}$ & 1.09 & $0.169^{* *}$ & $0.175^{* *}$ & $0.184 * *$ & $0.170^{* *}$ \\
{$[0.035]$} & & {$[0.035]$} & {$[0.035]$} & {$[0.028]$} & {$[0.053]$} \\
0.001 & 0.00 & 0.001 & 0.003 & 0.014 & 0.001 \\
{$[0.076]$} & & {$[0.076]$} & {$[0.076]$} & {$[0.048]$} & {$[0.076]$} \\
0.096 & 0.61 & 0.095 & 0.098 & -0.011 & 0.096 \\
{$[0.067]$} & & {$[0.067]$} & {$[0.068]$} & {$[0.059]$} & {$[0.068]$} \\
$-0.050^{*}$ & -0.32 & $-0.050^{*}$ & $-0.048^{*}$ & 0.024 & $-0.050+$ \\
{$[0.024]$} & & {$[0.024]$} & {$[0.024]$} & {$[0.025]$} & {$[0.027]$} \\
\hline 44,383 & & 44,383 & 44,383 & 44,383 & 44,383 \\
21,836 & & 21,836 & 21,836 & 21,836 & 21,836 \\
\hline
\end{tabular}

Audits (N)

21,836

21,836

Negative binomial coefficients or average marginal effects (AME), with standard errors clustered by the establishment's country in brackets. ** $\mathrm{p}<0.01, *$ $\mathrm{p}<0.05,+\mathrm{p}<0.10$. $\checkmark$ indicates standardized variables. Audit paid by factory and garment industry are the omitted baseline categories. All models include dummies indicating whether the audit is the factory's second, third, fourth, fifth, or sixth-or-higher audit during the sample period. All models also include year dummies, dummies for undetermined who paid for audit and industry undetermined, and dummies denoting instances in which number of auditors, audit team tenure, and audit skills training were recoded from missing to 0. Note 1: Column 3 displays results where prosocial attitude in buyer country is measured as the first factor resulting from a principle-component analysis with varimax rotation. Note 2: Column 5 displays results where standard errors are two-way clustered by both the audited establishment's country and the buyer's country. 


\section{Endnotes}

${ }^{1}$ Each of these domains includes a host of subcategories. The occupational health and safety category, for example, includes 7 items for emergency preparedness, 5 for fire safety, 8 for toilets, and 8 for the work floor. The latter refers to improper chemical storage, improper medical waste disposal, inadequate lighting, inadequate ventilation, lack of personal protective equipment, lack of chemical safety data sheets, unsafe electrical conditions, and unsafe machinery.

${ }^{2}$ Omission of these violation categories is not meant to imply their unimportance. Freedom of association rights, for instance, are among the most significant core labor rights recognized by the ILO. These categories are omitted from our analysis because they are known to be unevenly identified by social auditors from different countries and thus their inclusion risks yielding biased results.

${ }^{3}$ Estimating a model that used the unwinsorized count yielded nearly identical results, which are reported in Column 2 of Table 4.

${ }^{4}$ Although this variable measures the legal rights of workers to organize and does not directly measure the same occupational health and safety standards captured by our dependent variable, the labor literature documents a close association between the two. Because workers empowered to organize are also better able to advocate for higher working standards (Rodríguez-Garavito 2005), stringent legal protections for workers' freedom of association should indicate a domestic environment that is also protective of other workers' rights.

${ }^{5}$ Because studies have demonstrated that suppliers' adherence to global labor standards depends not only on a country's formal laws but also on how domestic regulators enforce those laws (e.g., Amengual 2010; Coslovsky \& Locke 2013), as a robustness test we substituted Greenhill et al.'s (2009) labor practices for labor laws. Labor practices measures the extent to which governments protect union organizers and members from persecution, prohibit firms from excluding union members from their workforces, and secure collective bargaining rights. This alternative model yielded results nearly identical to those of the primary model.

${ }^{6}$ We used questions V29, V32, V88, V104, V105, and V106 from the 2005-2006 World Values Survey. We reverse-coded the latter four so that higher values of all of these variables indicate a more prosocial attitude.

${ }^{7}$ Our primary approach avoids using sample-specific weights. As a robustness test, we instead conducted principle component analysis with varimax rotation and used the first factor (eigenvalue of 2.98) that explained 50 percent of the variance, which is a weighted average of the six items. Regression results based on this alternative measure of prosocial attitude in buyer country, displayed in Column 3 of Table 4, are very similar to our primary results and continue to yield a statistically significant negative coefficient on that variable.

${ }^{8}$ More direct measures of size, such as employment or production, were not available in the auditor's database and our efforts to match the factories in our sample to the Capital IQ and WorldScope datasets yielded very few matches.

${ }^{9} \mathrm{We}$ imputed undetermined industries by estimating a multinomial logit model of the industry categorical variable (with missing values for undermined industries) based on the number of labor violations, the number of labor violations in each of six subcategories (child labor, forced or compulsory labor, hours of work, occupational health and safety, minimum wages, and disciplinary practices), re-audit, third-party audit protocol, number of auditors, audit paid by buyer, and audit paid by vendor, agent, or licensee. We then created industry dummies based on this imputed industry categorical variable and estimated our primary model with these dummies. The results, based on multiple imputation in Stata and reported in Column 4 of Table 4, were nearly identical to our primary results.

${ }^{10}$ Because so many audits in our sample were of factories in the garment sector and were conducted in China, we also estimated our model on the subset of audits that excluded those conducted in China and those of garment factories. The results, based on 9,912 audits of 6,204 factories, were very similar to our primary results estimated on the entire sample. In particular, the coefficients on labor treaties, labor laws, prosocial attitude in buyer country, and GDP per capita of buyer country were of very similar magnitude and statistical significance. The coefficient on press freedom was somewhat less negative and statistically significant $(\beta=-0.15, p=0.06)$ than that in the primary model. The coefficient on INGO density was positive $(\beta=0.09, \mathrm{p}=0.05)$ whereas it was negative but non- 
significant in the primary model, perhaps suggesting that, in this subsample, INGOs are more active in countries with poor labor conditions.

${ }^{11}$ Results are reported in Column 5 of Table 4 . Two-way clustered errors are typically calculated by adding the variance matrices yielded by one-way clustering on the first versus the second dimension, then subtracting the variance-covariance matrix that reflects their intersection (Cameron, Gelbach, \& Miller 2011). In our empirical setting, this yielded negative diagonal elements of the resulting variance-covariance matrix (which prevents standard errors from being estimated), so we pursued a more conservative approach by not subtracting the variancecovariance matrix that reflects the intersection.

${ }^{12}$ The model fit statistics for a model that includes only industry dummies include McFadden's Adjusted R-squared $=0.002$, Likelihood Ratio $(\mathrm{LR})=458.9$, and Bayesian Information Criterion $\left(\mathrm{BIC}^{\prime}\right)=-330.5$. The model fit statistics for a parsimonious version of our primary model that omits supplier-country variables are McFadden's Adjusted R-squared $=0.033, \mathrm{LR}=8506.8$, and $\mathrm{BIC}^{\prime}=-8132.3$. The model fit statistics for a parsimonious version of our primary model that omits buyer-country variables are McFadden's Adjusted R-squared $=0.045, \mathrm{LR}=$ 11807.8 , and $\mathrm{BIC}^{\prime}=-11390.5$. The likelihood ratio value of the primary model is statistically significantly larger than those from these alternative models ( $p<0.001$ for each comparison), and the differences in BIC' values between the primary model and each alternative model — differences of 11834.6, 4032.7, and 774.6, respectivelyconsistently provide "very strong" support for the full model.

${ }^{13}$ Our results are robust to potential concerns that domestic law is sometimes incorporated into codes-of-conduct. Factories subject to such codes in countries with stringent domestic law must comply with more requirements than factories in countries with lax regulation. If these particular code requirements were driving citation rates, factories in countries with more stringent domestic law would be expected to exhibit more code violations because they face more compliance challenges and codes incorporating stringent domestic law would provide auditors with more potential violations to cite. To the contrary, we theorize and find empirical support for an institutional effect of regulatory stringency: Factories in countries with more stringent domestic labor law are more likely to adhere to the potentially more stringent requirements of their codes of conduct.

${ }^{14}$ The high correlation between prosocial attitude in buyer country and GDP per capita of buyer country led us to explore models that omitted each of these factors, which yielded remaining coefficients nearly identical to those in our primary model. 